switch to the full-length white-framed mirror of my mind. I lie waiting for the approaching great.

The early mirror mist slowly lifts, revealing a landscape of fescue \& jonquils. A golden motorcycle has risen on the horizon. Soundlessly it glides to a stop beside my outstretched shape.

Permit me to translate your name to Small-Bear Miller: the rider says to me: It facilitates the introduction.

\title{
Ossa Eats Doilies, Some Say Antimacassars: A Rondez-Voos w James / Kent H. Dixon
}

\author{
To: Kent H. Dixon \\ 1011 N. Summit St. \\ Iowa City, Iowa
}

1 February 1970

London, England

Dear Kent . . .

Thanks for staying in there with the little book project. I would say the enclosed four, plus the Borges piece, Merwin's DWELLING, Chambers's CAKE, and your MARY, MARY were all in. How many more can Kim print? Right now we could add four or five, something by Persinger (if you insist), Kelly's OPERA, Vogelsang's A FILM OF OUR ... BUT FIRST, and then as you say, there's Aukema, Kosinski, Hawkes, Barth, Gass, et al. I'll write Barthelme c/o NEW YORKER.

As for your writer's cramp, yes, writing is full of suffering and exhilaration, but you have to do it to do it, Kent. To fail to choose to write is not the same as to choose not to write. There's a depressing obverse to this, but it's not your problem (talent and commitment can yield nothing, go undiscovered even by other writers; think of the close calls-Dickinson, Kafka, West; think of the ones that got away; things could be very different).

Sorry to hear how hard it is for you and Errin to make a steady go of things. Iowa City is not known for its stable relationships. If you're not presently enrolled, why not settle someplace else for a time. It's taken an ocean and fifty miles of country roads, but it's reduced our visitors to only the most 
earnest family and bill collectors, and since I work nights . . . I suppose Errin wants to be near the University though. Stimulating, if not always productive.

I truly appreciate your sticking with this thing. Without your saturation letter-writing we wouldn't be even this far, but don't neglect your own work, I mean the writing.

best,

Bob

Arthur Vogelsang

314 W. 3rd Street

Wichita, Kansas

April 12, 1970

Dear Buddy,

I think I left my football at your house. Try the dog's room. I think I saw him eyeing it. I did not see anything like what you complain of. In fact, I thought she was nicer to me than him. Lev Persinger is a supercilious jamoke. He's envious and afraid of you. I can't imagine that Errin finds anything there beyond the momentary satisfaction of getting a jackass to bray on cue. Titania and Bottom. . Wall. . Moon. . It will pass.

Speaking of, the name of my football is Rose O'Sharon. Pack it good, ok? It really is a source of exercise and meditation and I miss it.

Came home to some good news-while we were away Jon and Tony wangled a $\$ 2500$ grant from the Kansas Cultural Arts Commission; so we're breaking even. Next issue out by fall. Changing the name to Ark River Review. Favoring Kansans, natch, but worthy outsiders too. You will send us something, yes? Soon, before either of us becomes too famous.

I spread the word here about the Coover project. You should hear from some.

Judy sends love. Was a lovely visit, she says, esp. after the Des Moines gig, she says. Not to make her sound moronic, she says, in fact, she says (She's got them wrapped around her pinky at KPTS, but how long, eh? She's starring me-heh, heh-in her latest talk show):

Kent-

It's mostly true, especially the visit. Thanks. Terribly rushed at the moment. We're staging an editorial meeting in the living room (for filler, for the show), and we're shooting in 25 minutes, make that 22 minutes (A. reading over my shoulder), and the film isn't loaded (still thawing out), can't find the sound man (not A's favorite job as you will recall), no Jon 
or Tony, and the damn cats have just knocked over a kleig light. Time only to repeat, thanks, very, and to bring on the mundane: Could you please, along with A's football, please send 2 tooth brushes, one razor, hairbrush and comb, and bottle of Cope-all in downstairs bathroom.

Less than 20 minutes and still snafu. I'll keep writing. This talk show I'm doing is on little magazines and will have as guests (among others) Jon, Bruce Cutler, and someone I think we forgot to tell you about in the flurry of Iowa City. He went to the Des Moines Writers Conference with us but I never saw him after we arrived, so forgot to mention. Where was IP James Mechem-you'd love him. He's about 45-47, painfully thin, looks young, works as a technical writer at Beech Aircraft (incongruous enough?) and has written hundreds and hundreds of short stories-all wild, some boring, but consistent in style. Most are sexy, but the painful side. Whacky yet convincing, the feeling. I suspect all his exotic honeys are really muses in designer bikinis, but they have an authenticity in the way they put him down, and you like him for it. I guess it's that absurd male ego bid for sympathy once more, but it sort of works. I want Arthur to send you some to consider for the Coover book. The very short are best, I think. The sort of deadpan-downbeat-absurdist-metafictional bag, but he's been doing it a long time, might be a pioneer. Where does all that begin anyway? that flat effect that's so funny-sardonic? Camus's Meursault? Beckett's tramps? The underbelly of the fifties. Arthur says Dostoevsky's Underground Man and that he's read Coleridge. Ol'Arth, wrong again. Let's get this right: it's a Tolstoy's Pierre translated by Robbe-Grillet while visiting Richard Brautigan in Boca Raton. Ok? At any rate, he's an enthusiastic person, funny, given to affable put-ons, and with lots of opinions about poetry and fiction. He comes to their workshop on Tuesdays, so I go regularly now (but you can still send the Cope). Subscribes to over 50 little magazines, has 5 children and his wife is a member of MENSA. You'll have to meet him at some point.

Time's up. Film should be thawed out by now. Arthur fixed the light. My Arthur. I don't agree with him, by the way, about Lev and Errin. I tend to agree with you, but I hate to get into it, you know me, so much safer/ saner behind the camera. One sisterly word of advice: don't act on the jealousy so much. It repels. Be blithe. Not exactly your style of relating, but give her her head, she's young. Sounds easy enough to say, I know, but don't forget, Lev-baby starred in two of my films and I know how fundamentally boring (if sexy) he is.

Sound man's here. Bye.

Love, Judy 
Coover

England

June 3, 1970

Rushed, Kent . . .

Enclosed is my ENCOUNTER and rough draft of a prefatory thing-why don't you see what you can do to enlarge upon it? or otherwise improve it. Maybe something else altogether. We'll omit Morgan. I missed Cortázar by a day, but finally have Topor's permission to use anything of his. In particular, he gave me a funny little book all about shit, and I'll try to work up some kind of translation of a piece of it and send it along. Meanwhile (to allay your doubts), all writing is derivative; all language is derivative after all; all writing is also unique; all experience is unique after all. Old forms generate their own cul-de-sacs, and solutions are discovered simultaneously by many writers, sometimes in community. Everyone's derivative. Unique. Don't worry about these things. Keep writing.

best,

Bob

PO Box 8004

Wichita, Ks.

10/28/70

\section{DEAR KENT DIXON:}

Arthur Vogelsang suggested I send you some of my shorter stories for consideration for an anthology you and Robert Coover are putting together. Quod vide, as they used to say, in Rome, I guess. If you don't like these I could send more. There's a lot.

I read something of yours recently at the Ark River Review offices which rather depressed me (customary measure of my esteem), and I was wondering if you would be interested in editing an issue of my Out of Sight-no great shakes and not to smack of tit for tat neither, but we do have a lot of fun with it, several copies enclosed herewith, q.v. It's presently in the capable, lovely, and bloody unreliable hands of one Ossa (cf. story entitled "Ossa Eats Doilies, Some Say Antimacassars"). I'm miffed enough to tell you her real name, which she changed when she became a poet. If I can get the press back from her, or persuade her to set another issue with you as Guest Editor ... well, if you're interested write c/o OOS, Box 32, Wichita, Ks. 67201, one of us is sure to get it.

Hope you like the stories. Think about OOS.

Regards,

James Mechem 
OOS

Box 32

Wichita, Ks.

[no date]

\section{DEAR KENT DIXON:}

Thank you for your interest in OOS. However, I am not currently the custodian of it nor is it in any way, as you put it, my organ. It's pure Papa James. He lends the works out to anyone who speaks anything near fluent English (on the barrel-of-monkies-with-uno-typewriter-producing-Shakespeare theory, I think) and consequently it has temporarily gone thoroughly underground. But send what you already havewe work cumulatively around here, like rain clouds, little hopeful rainclouds in Kansas.

\section{Ossa}

[signed with an holographic “O."]

Coover

London, England

5 February, 1971

Dear Kent . . .

Sorry to hear of the temporary separation. There's hope: maybe it's not temporary. Buck up, Men have died from time to time and worms have eaten them, but not for love, as the bard said. You use pain for an escape, you know. The secret to that is, however, not to feel too badly about yourself, since that is all you really have to work with. Keep working, it cuts most recovery times in half.

Barthelme writes: "Of course. No problem. Wear it in good health." That would be through the second paragraph of BRAIN DAMAGE beginning "The humanist position ..." and ending "The blue of the flowers is extremely handsome against the gray of that area." Am returning the Mechem stories, one old Persinger, and one Elie Wiesel letter (I think this constitutes permission). And a Brautigan. Okay, okay, omit the Persinger. I thought the Mechem stuff was funny (internal jokes, juxtapositions, groaners along the marrow, etc.) and worked well in short compass, but still a little thin. Beginnings are good. Endings are weak, which may be inherent in the subject. Omit. 
I agree Brautigan should be in there and I think my apologies about the incompleteness of the collection (in the intro)-that this was more a project among friends than an anthology selected by God-were largely with the absence of Brautigan in mind. He's flimsy, often empty and careless, but he's also his own man and he's often very compelling. I was an early (Evergreen Review) fan of TROUT FISHING and still like him as a writer, but in fact I felt lazy about writing yet another letter. I've met him and am absolutely sure he'd be delighted to give us something, very generous man and much moved by projects such as this. You should get a quick reply, and choose something better than the enclosed if you prefer. Should say, also, I have the feeling this Mechem's going to be a good writer someday, given ten years or so. We can always look at him again then if we're wrong now. At the rate we're going he may yet get in this one. We've got 17 or 19 now, depending; let's wrap it up.

best,

Bob

\section{Vogelsang/Wichita \\ [Postcard]}

Well look, buddy, hang it up. I never liked her toes anyway, too close together. Judy says same, also for fingers. Wichita resembles a sound and light version of the playing surface of a pinball machine, but it's better then yr mom's in Miami because both of us are here, home sweet, and yours for as long as it takes to grow back yr manhood. Not to feel diminished about that either, sweetheart, you have the best of company: Lawrence, Henry James, Harry Emerson Fosdick ... our very own Cecil . . . myself even (don't tell Judith) has had a hard time peeing of late, though that may be due to the cheap gin. So where are you? No answer at $N$. Summit. Call us immediately, Love, A.むJ. (Wichita si, Miami no, ok?)

\section{OOS}

Box 32

Wichita, Ks.

circa 1971

\section{DEAR KENT DIXON:}

I sort of like your idea of a "pen-is-pal," though can't say much for the vehicle. You're on, at least until we meet. No photographs, but I will confess to having smallish dark-pupilled eyes. Recent history (see if I can equal your candor): I met Papa James the night my VW camper burned up with 
all my manuscripts and plants, and moved into the Mechem basement and did nothing for a year and a half. That's not quite accurate. I did manage to fall asleep everytime somebody put his hand on my arse, and finally got out of that with the help of TM, then had to get out of TM (destroyed my drinking), wrote endless movie reviews and some technical crap for the aircraft companies, had a musical play produced in a local restaurant, fell in love with the star (female), a genuine autistic who treated her goddam guppies better than me, left her and switched back to men, switched off of acid and candy and abortions, and finally finished my MFA which put me on equal terms with the artistic community around Wichita State-unemployed and dull. Except Papa James and Vogelsangs and one or two others. Yes, Jon, since you ask. I'll admit it's interesting being made love to like a wash tub base, the first few times, though I guess I prefer the winds. Embousure, why not?

Your own vita sounds less checkered than circular. Why don't you let the little bitch go in good riddance. No, I haven't met her yet, but she's at the Vogelsangs a lot and I will enjoy having the goods on her when the time comes. As for the sex problems, try not to worry. Worry's the problem, in fact, as you must know. Once I couldn't cum for about six or eight months and then all of a sudden I could cum again. I was sitting in a public toilet listening to some rock music and zingo. As Papa James say in his Diary of Women, It's all in the head. It might have had something to do with the drugs, too. Also, I had a sympathetic shrink. Good music, too.

I liked your poems, especially the two about me. Send more. Ossa.

PS: I might be in I.C. next month. Could I crash at your place? If nothing else, it'll drive Errin up the wall, and in all seriousness, we could work on some of those finer editorial problems-delete and insert, etc., hm?

O.

\section{Vogelsang}

Wichita-a-Go-Go \& Co.

Chief Gofer

June, 1971

Believe me, Buddy, I was as surprised as you were. She's doing okay, however, esp since that shmuck Persinger left.

Of course I know who Ossa is-she eats doilies, right? some say antimacassars. I don't understand your other questions, probably because I'm off my feed. I mean it suddenly feels awful to know you're (I mean me) a weak person and will write the rest of your life. You ain't the only one. There's this giant spoon dipping down from the ceiling following me 
around / passing me by . . . which reminds me, more bad news. You didn't win the Ark River Review Annual Fiction Award. Jon, Tony and I couldn't agree on anything, and then they left, Jon Ohio Tony Utah, so last week we chose cards on the telephone and Jon had a 10 of clubs, Tony a 5 , of diamonds I think, and me a deuce. I think Jon gave the whole $\$ 100$ for fiction to William Kittredge. Don't tell anybody. I picked you, Mechem, Sahatdjian, equally.

This documentary Judy's doing on the Go-Go scene in Wichita (lots of interviews with the girls, their parents, the customers, etc.) is really gonna be good, except for the legal problems, but I don't know if she can use you. Here:

$K-J u d y$ here. This is difficult for me. Please try to understand. The legal problems were restricting us too much so I switched to actors (the discotheques were letting me use some footage and some interviews, but not together. Also they wanted final cutting rights.). I hope you don't mind, but your Errin was around so much, badgering everyone for jobs, what a great worker she was, etc., that I took a chance and hired her and she's working out great-easy to work with, beautiful to look at, and a natural with the bump and grind. She walks around topless off camera and I suddenly have more sound men and gaffers than the studio can hold. Arthur is doing make-up and James (Mechem) plays her father, who is very much concerned with the artistic side, I mean his character is. Actually I'm not sure it's a character at all-he wears the same frumpled rain coat he always does, and the scene in which he coaches her on how to bow (he keeps fussing and pulling down her shorts in back, I mean lower, so as to cover her thighs, this while she's topless!) is so incredibly funny and poignant you'd swear they were both playing themselves. So anyway, dearest, second most important man in my life, I would always love to see you and can use your help, but I suspect you heard that Errin was working with us and I don't quite trust your motives. This is the best thing I've done yet and there's only one more week of shooting and I'm afraid you'd wreck the rapport we've got going. So come, if you can behave, but don't mess me up. Think it through. Don't torture yourself; I don't know if she wants a reunion. She was neither here nor there about it when I said you might be coming, so if you come with the wrong expectations you could be shocked and react and botch everything. What about this: It's over a week from tomorrow, her part, the 8th. Mechem goes on his vacation then to Miami Beach with his family, so it has to be over, and Arthur and Tony leave the next day on a reading tour, and I've got an interview in NYC for the Philadelphia job. Errin's house-sitting so you could have the entire place to yourselves, except for the cats, and whatever other madness you're concocting (what's all this Ossa stuff? I don't 
know any Ossa), optimum conditions for reconciliation, right? Let me know about this. Please understand my position. I really don't think you could handle the present scene and I really couldn't forgive you if you loused it up. Don't be angry; be my friend and understand.

My love always,

$$
J u d y
$$

[5 YEARS LATER]

Coover

(from England)

8 July 1976

Dear Kent . . .

[** * ]

Also at present working up a small feature on the writing of James Mechem. Do you know his work at all? A curious man who publishes mostly on selfdestruct tissue and lives away his life in Wichita. I plan to run a small retrospective of his fictions, hopefully accompanying it with pieces from other people-straight criticism, bent criticism, brief appreciations or reminiscences, parodies, fictions or poems in which Mechem is a character, or in which his characters are characters, or in which he or his characters or his writing get talked about by other characters, and so on. Just about anything in fact that relates to this playful author.

Would you be interested in having a go at some contribution to it? It wouldn't have to be anything grand or difficult-or even all that far out, if you didn't feel like it. We're gathering some of his things together now at Iowa and could send you copies of what we've got, or some of it anyway (there's a lot), if you wanted to try something but needed to read more first. Let me know.

Use the Review address by the way, as I'm shortly in transit for a while. Hope your own work is going well ...

\author{
best regards, \\ Bob \\ Robert Coover \\ Fiction Editor \\ The Iowa Review
}


P.O. Box 8004

Wichita, Kansas

$11 / 4 / 76$

KENT:

I think this issue of IR is going to be fun, don't you? All my friends are busy with their pieces. But you, Kent, I didn't expect you. I know you still don't believe me about that ancient unpleasantness at the Fontainebleau, but the story hasn't changed: Errin did come along at the last minute as the babysitter; my wife did happen to be out shopping that day; the kids were at a movie in the hotel; you saw the bellhop before I did; we were only sunbathing (everyone got used to her going around like that at the TV station, I didn't even notice any more ). I finally settled out of court with the hotel, by the way, you might be glad to hear that. Errin, predictable as ever, went on to Japan from Wichita; no word in the past three years.

As for "Ossa" and life between inverted commas, well, here's the copy of "Ossa Eats Doilies, Some Say Antimacassars" that you asked for. It's a pity you didn't read it more carefully six years ago. I swear I thought that you were putting $m e$ on-all those poems and love letters, old pen-is-pal!-or that we were collaborating on something, like a story. Anyway, here it isand at least the chocolates were real, eh?

Good luck with the epistolary blague. I just hope you can say something awful about me without trying to be funny about it. That's all I ask.

Was at Tony Sobin's house last night for a birthday supper of the woman he lives with. Her name is Teddi Todd and she's the current editor of MIKROKOSMOS. Why don't you send something, c/o English Department. It will get to her (I promise). Check it out ...

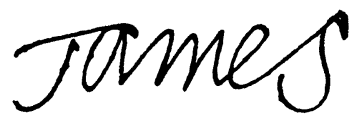

\section{In Le Bardo There Is a Head of Jupiter as Tall as a Woman / James Mechem}

I'm a travel writer who hates to travel. It's true. If there's one thing I hate worse than traveling it's being a tourist. 